\title{
Agricultural landscape pattern and agricultural tourism potential of Nevsehir*
}

\author{
Aslıhan TIRNAKÇI ${ }^{1}$, Esra ÖZHANCI ${ }^{1}$, Meliha AKLIBAŞINDA $^{1}$
}

${ }^{1}$ Nevşehir Hacı Bektas Veli Unıversity, Faculty of Engineering and Architecture, Department of Landscape Architecture, NEVŞEHİR

*This study was presented as an oral presentation and published as an abstract in International Conference on Agriculture, Forest, Food Sciences and Technologies.

Alınış tarihi: 4 Aralık 2017, Kabul tarihi: 5 Mart 2018

Corresponding author: Aslıhan TIRNAKÇI, e-posta:aslihanerdogan@nevsehir.edu.tr

\begin{abstract}
Agricultural land being shaped depending on soil, climate and land structure, and consist of various size which vary from thousands of acres of land where a particular crop is grown to smaller formal gardens. Agricultural landscape is a sample of transition from natural landscape to cultural landscape, and it has emerged where people began growing crops for economic purposes. Besides the production of agricultural products, agricultural landscapes also have ecological, economic and social impacts such as soil protection, cultural green texture and creating aesthetic appearance, creating a living environment for the wildlife and contributing to tourism. Agrotourism, by combining agriculture and tourism, offers new sources of income for farmers. In this context, in recent years agricultural tourism is becoming increasingly important within the framework of sustainable tourism. In this study, distribution and parceling forms of agricultural landscapes that shaped the agricultural landscaping pattern of Nevsehir have been revealed by field survey, and rural settlement plan was created by specifying the characteristics of agricultural settlement types. Then, the potential of agricultural tourism, which one of the nature-based tourism activities that support the development of rural areas in the region has been assessed. Also possible applicable models for Nevsehir were put forward. As a result, viniculture in Nevsehir province, which has an important share in the regional economy, is important in terms of agricultural tourism. However, the economic problems experienced by the producers and the low incidence of the vineyard affects the viniculture culture nega-
\end{abstract}

tively. In this context, agricultural tourism is important in terms of supporting and strengthening rural development in research area.

Key words: Agricultural landscape, agricultural tourism, Nevsehir, rural landscape

\section{Nevşehir ili tarımsal peyzaj deseni ve tarımsal turizm potansiyeli}

\section{Öz}

Toprak, iklim ve arazi yapısına bağlı olarak şekillenen tarımsal araziler, belirli bir ürünün yetiştirildiği binlerce dönüm arazi ölçeğinden, bir dönümden daha küçük formal bahçelere kadar değişkenlik gösteren farklı ölçekteki alanlardan oluşmaktadır. Doğal peyzajdan kültürel peyzaja geçişin örnekleri olan tarımsal peyzajlar, insanların ekonomik amaçlarla tarımsal ürün yetiştirmesi sonucu ortaya çıkan peyzajlardır. Tarımsal peyzajların tarımsal ürün üretiminin yanı sıra toprak koruma, oluşturduğu kültürel yeşil doku ile estetik görünüm yaratma, yaban hayatına yaşama ortamı oluşturma ve turizme katkıda bulunma gibi ekolojik, ekonomik ve sosyal olmak üzere çok yönlü etkileri vardır. Tarım ve turizm faaliyetlerinin birleştirilmesiyle oluşan tarımsal turizm, üreticilere ek gelir kaynakları sunmaktadır. Bu bağlamda, son yıllarda sürdürülebilir turizm çerçevesinde tarımsal turizm gittikçe önem kazanmaktadır. Bu çalışmada Nevşehir ilinin tarımsal peyzaj desenini şekillendiren tarım arazilerinin dağılımı ve parselasyon biçimleri yapılan arazi gözlemleri sonucu ortaya konmuş, tarımsal yerleşim tipi özellikleri belirlenerek kırsal yerleşim planı oluşturulmuştur. Daha sonra bölgede kırsal alanların gelişimini des- 
tekleyici doğa temelli turizm etkinliklerinden biri olan tarımsal turizm potansiyeli değerlendirilmiş, bölgede uygulanabilecek olası tarımsal turizm faaliyetleri ortaya konulmuştur. Sonuç olarak Nevşehir ilinde bölge ekonomisinde önemli payı olan bağcılık tarımsal turizm açısından önemlidir. Ancak üreticilerin yaşadığı ekonomik sorunlar ve bağcılığın getirisinin az olması bağcılık kültürünü olumsuz yönde etkilemektedir. $\mathrm{Bu}$ bağlamda tarımsal turizm araştırma alanında kırsal kalkınmanın desteklenmesi ve güçlendirmesi açısından önem taşımaktadır.

Anahtar kelimeler: Kırsal peyzaj, Nevşehir, tarımsal peyzaj, tarımsal turizm

\section{Introduction}

The areas shaped by the interactions between man and his natural environment, formed by social, economic and cultural influences are called cultural landscapes (Özsüle, 2005). A cultural landscape is differs from other landscapes due to the purposes and forms of use of nature by societies, and is divided into two as urban and rural landscapes. Rural landscape is a transitional zone between human and natural landscape (Dirik, 2005). Cultural forest landscape, agricultural landscape, industrial landscape and recreational landscape are rural landscape forms that emerge from people's occupations.

Agricultural landscapes, a subcomponent of rural landscape, are the areas where people make agricultural production in accordance with their economic goals (Weersink, 2002). Agricultural landscapes, which are the first examples of cultural landscapes, can range from thousands of acres of rural tracts to a small homestead with a front yards of less than one acre. Agricultural landscapes are shaped by structural, functional, and administrative features of the area. These include natural features such as topography, geology, soil, climate, hydrology, flora and fauna, as well as features such as cultural structure and ecosystem function. Agricultural areas in agricultural landscapes can be expressed as stain, matrix and corridor patterns in terms of landscaping techniques (Karadeniz, 2013).

Agricultural land and agricultural settlements constitute the agricultural landscaping pattern in an area. The agricultural landscaping, shaped by natural, social development level and technology, has changed in various ways; and consequently, different landscape patterns have emerged. The field sizes have increased especially with the mechanization agriculture, and the fields and gardens of old small parcels have disappeared (Akdoğan, 1984).

The agricultural landscape in Turkey is quite large and covers a wide area. The fact that our country has wide varieties in terms of growing environments with mainstream and transition climate types increases the product variety in agriculture.

As a result of this, very different types of agricultural landscapes that characterize many different regions and areas have emerged. For example, it is possible to see agricultural landscapes with different characteristics shaped by tea and hazelnut in the Eastern Black Sea Region, grains in Central Anatolia, sunflower and cereal in Thrace, and olive trees in the coastal Aegean (Dirik, 2005; Gökalp and Yazgan, 2013).

The busy and stressful urban life further increases people's need for recreation. Therefore, in recent years, different alternatives have been added to tourism options for people who long for nature and natural life. One of these options is agricultural tourism, which is one of the components of rural tourism (Türkben et al., 2012). Agricultural tourism is an important concept within tourism mobility in rural landscape formation. Indoor accommodation or camping in a farmstead, educational visits, dishes, recreational activities and farm products or selling of handicrafts are considered in this context (Roberts and Hall, 2001).

Agricultural tourism performed in areas where agricultural production is intensified not only provides the conservation, promotion and sustainability of natural and cultural landscape values, but also brings additional income to producers as well. In this context, agricultural areas, which are frequently seen in the developing regions, are not destroyed for the sake of tourism business, and thus, tourism develops along with agriculture. Consequently, agricultural production is integrated with tourism (Küçükaltan, 2002).

This study investigates the agricultural landscaping, agricultural land and agricultural settlements of Nevsehir province whose entire economy is based on agriculture. As a result of the field observations, the characteristics of the agricultural settlements were determined, and a rural settlement plan was established. Additionally, the agricultural tourism potential that will support the development of the rural areas in the region was examined, revealing the agricultural tourism activities that can be implemented in the region. 


\section{Materials and Methods}

The main material of the study is the province of Nevşehir, which is interesting in terms of natural and cultural landscape values and tourism. Nevsehir is located between $38^{\circ} 12^{\prime}$ and $39^{\circ} 20^{\prime}$ northern latitudes and between $34^{\circ} 11 \mathrm{~N}$ and $35^{\circ} 06^{\prime} \mathrm{E}$ longitudes in Central Anatolia Region. Except for Derinkuyu district, which is located in Konya closed basin, the total area of the province, which is within the Middle Kizilirmak Basin, is $5392 \mathrm{~km}^{2}$ and the altitude is 1150 meters. The province is surrounded by Kayseri's Yesilhisar, Incesu and Central districts in the east; by Bogazliyan and Sefaatli districts of Yozgat in the north east; by Nigde, Aksaray and Ortakoy districts in the south, southwest and west (Anonymous, 2017a),(Figure 1).

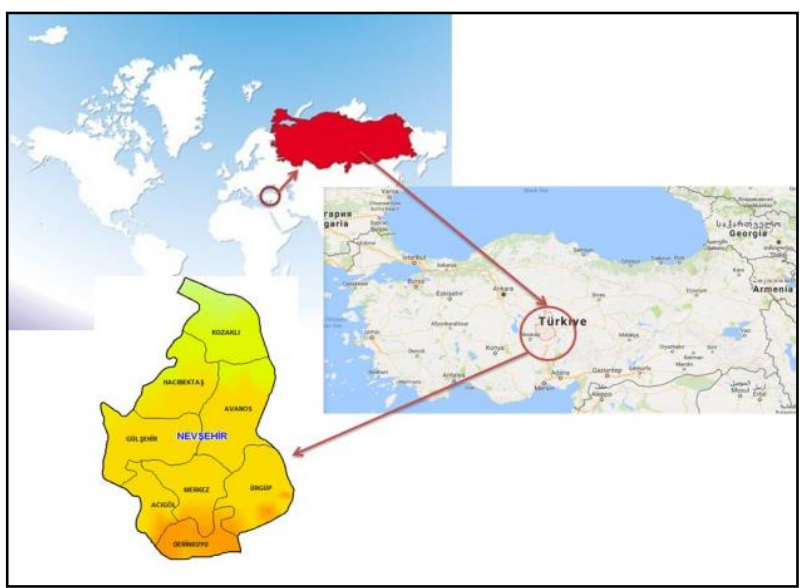

Figure 1. Geographical location of the study area

Nevşehir has a typical continental climate with hot and dry summers and cold and rainy winters. Steppe vegetation is dominantly seen in the area. The steppe vegetation is green in the spring, and gets dry with the advent of summer heat. The natural vegetation of the province is complimented by the cultural green areas consisting of salix (Salix babylonica, Salix nigra), populus (Populusnigra), cupressus (Cupressus $s p$.), and vineyards and gardens along the valley and stream corridors. $97 \%$ of the area of the province is suitable for agriculture, but agricultural products are not very diverse owing to seasonal and rainfall conditions. Cereals, tubers and industrial products are the main agricultural products. In terms of the production of potatoes, Nevsehir province is the third after Nigde and İzmir. Additionally, fruits like grapes, apple, pear, walnut, mulberry, spindle, quince and almond; and vegetables like sugar beet, wheat, barley, rye, broad beans, chickpeas, beans and lentils are grown in the province. In this context, vegetable cultivation is improved, but fruit cultivation is espe- cially important in viniculture agriculture (Anonymous, 2017a).

The method was defined as data collection, observation, analysis and evaluation. In this study, which is aimed to evaluate the agricultural tourism potential of Nevşehir, firstly the agricultural landscape design of the study area was examined within the framework of agricultural land and agricultural settlements. A SWOT analysis was then carried out in order to reveal the agricultural tourism potential; and proposals for the development of agricultural tourism opportunities were introduced. Consequently, it may be claimed that the development of agricultural tourism in the region will ensure the socio-economic development of local people while preserving natural and cultural landscaping resource values.

\section{Results}

\section{Agricultural landscaping pattern}

The agricultural landscape character of a region is determined by natural factors such as topography, soil structure, water, climate, customs, and cultural factors. For this reason, the character of agricultural landscapes varies from country to country, even from village to village. The agricultural landscaping pattern of a region consists of agricultural lands (agricultural parcels, roads, grasslands, greenhouses, terraces, water channels, green textures provided by agricultural products, tree communities preserved in agricultural areas, cultural green areas created by road plants and home gardens) and agricultural settlements (dispersed and compact rural settlements).

\section{Agricultural land}

The economy of the rural settlements of the Nevsehir province is based on agriculture and there are very large-scale businesses carried out as well as smallscale family businesses. As the general land structure is flat and slightly inclined, the agricultural production is carried out in large, rectangular regular/irregular parcels (Figure 2). The settlement character of the region is the lowland village, where agricultural lands and residential areas are located apart from each other, and rural settlements are surrounded by irregular farming areas. However, in the rural settlements where fruit and vegetable production is carried out, the gardens are located close to the houses. Except for Derinkuyu, Kozakli and Kaymakli districts (the central district), the province is divided into small parcels due to inheritance (Figure 3). 


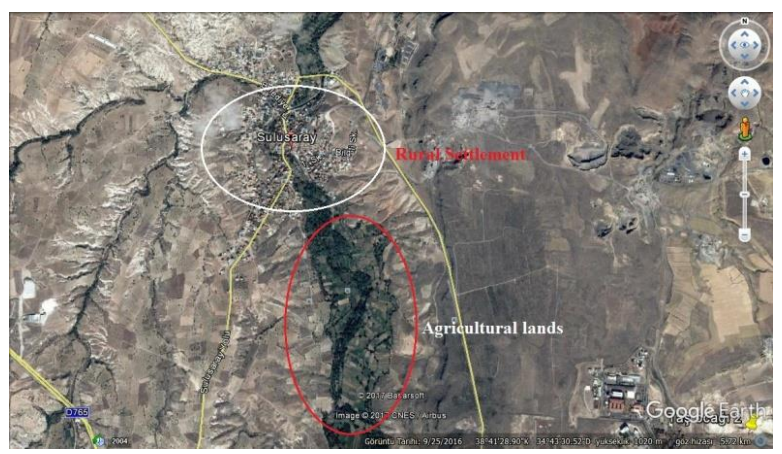

Figure 2. Agricultural lands located far from rural settlements (Google Earth)

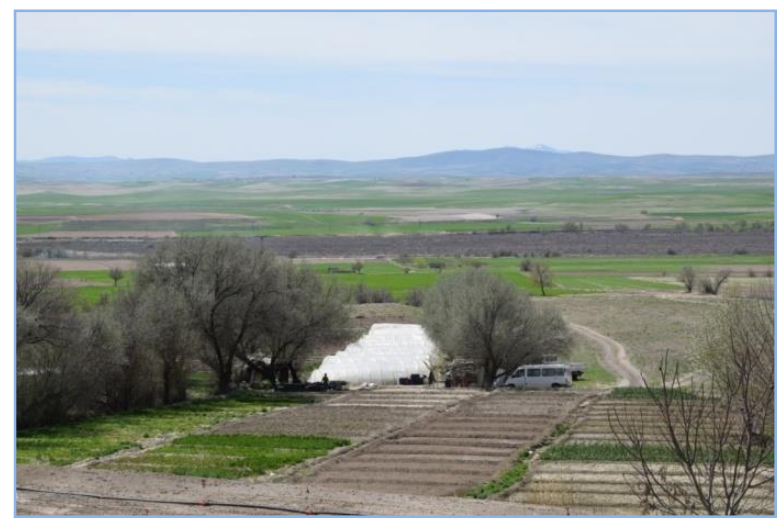

Figure 3. Divided agricultural lands

Climate, soil structure and the scarcity of irrigable lands are the most important factors affecting the agriculture in the region. For this reason, dry farming is generally performed. The agricultural production pattern of the study area comprises in Hacibektas, cereals and sugar beets; in Gulsehir, cereals, sugar beets, vegetable growing and viniculture; in Derinkuyu, cereals, sugar beets, potatoes and dried beans; in Urgup, viniculture; in Kozakli, cereals; in Avanos, viniculture.

\section{Agricultural settlement}

Nevsehir Province is located on a very wide plateau formed by the accumulation of ash and lava of old volcanoes such as Erciyes, Melendiz and Hasandagi in Central Anatolia. The rural settlements are generally lowland villages with flat and slightly inclined terrains. Large flat areas are restricted by mountains and hills. Due to the economy in the region, settlements have developed in the form of compact settlement form. In general, the rural settlements are surrounded by agriculture parcels dispersed organically from a center along the main road (Figure 4).

In this context, transportation routes have constituted an important factor in the formation of the settlement form. Houses have been located close to each other and the rural settlements have formed a compact structure (Figure 5).

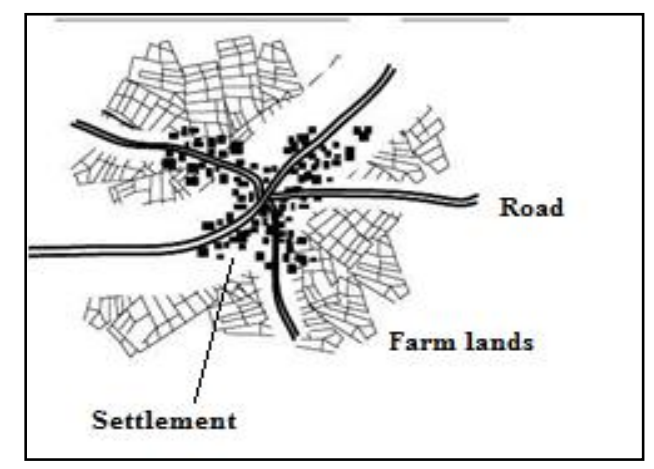

Figure 4. The settlement plan of lowland villages

However, in the provinces of Avanos, Urgup and Gulsehir, where vineyards are concentrated, habitats and vineyards are separated from each other and the settlements built in the vineyards give a dispersed form to the rural settlements (Figure 6).

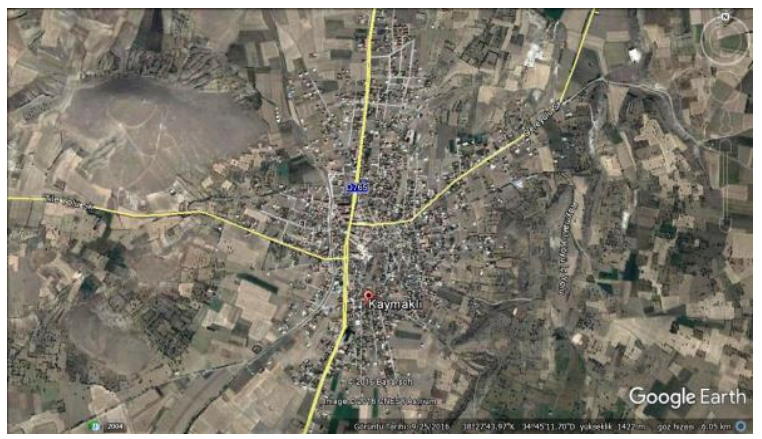

Figure 5. The rural settlements are in the form of compact settlement (Google Earth)

The old settlements of the districts such as Avanos and Urgup are located in the foothills of the mountains, the production areas have developed on flat land. Traditional residences have been built progressively in layers in order to benefit from the sun and enjoy the landscape (Figure 7). The settlements are located at the foot of a mountain in these settlements (Figure 8), the houses are located close to each other; the streets are narrow, reach to the mosques, which are the center of the rural settlement.

\section{Agricultural tourism potential}

Agricultural tourism is defined as a collection of activities directly related to the rural environment products, farming with accommodational facilities, camping or hostel accommodation, educational excursions, eating and drinking, recreational activities and the sale of crops and handicrafts on farms. Within agricultural tourism activities are; actively taking part in the production of agricultural products; collection of products; purchasing of fresh farm 


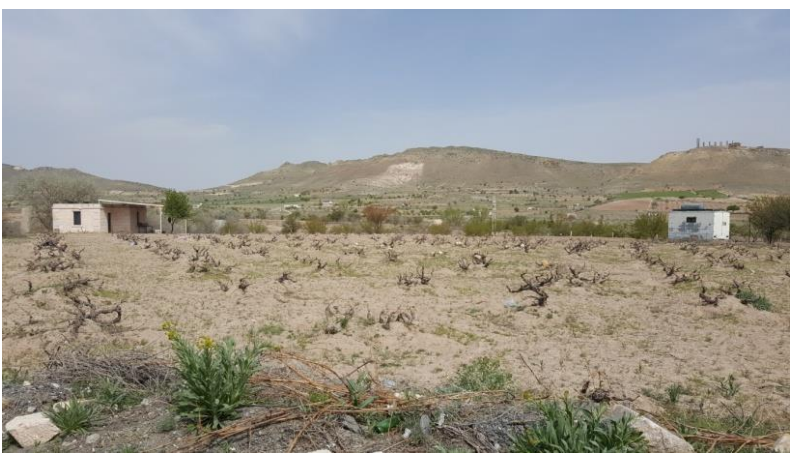

Figure 6.The vineyards and shelters built in them create a dispersed settlement form

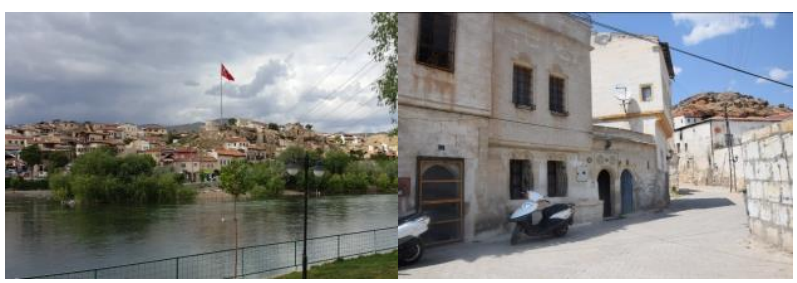

Figure 7. Mountainside settlement and alley street structure

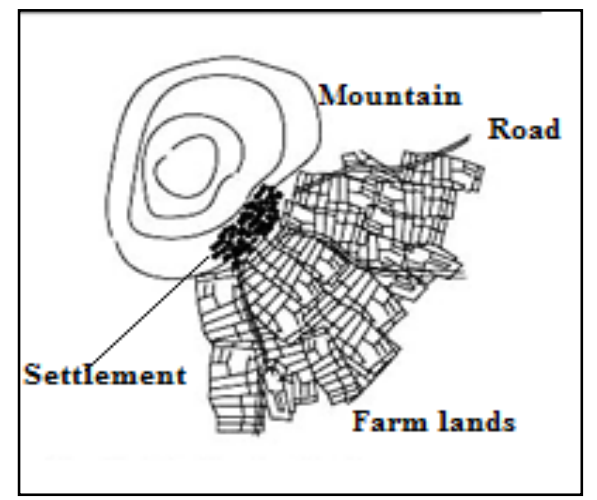

Figure 8. The settlement plan of mountain foot villages

products or region-specific pastries, home-made products such as pulps, tomato paste, pickles, cheese, wine, soap; learning the cultural richness of the region such as music, folklore, traditional costumes, joining festivals; interesting in crafts such as weaving, stone processing, metalworking, pottery etc., which are specific to the region and purchasing of the products (Aytuğ, 2011).

Nevsehir is located in the Middle Kizilirmak Basin in the Central Anatolia Region. Located in the middle of Turkey, Nevsehir has an area of 5,467 $\mathrm{km}^{2}$. There is an international airport in Gulsehir. It is also $81 \mathrm{~km}$ away from Kayseri, $287 \mathrm{~km}$ from Adana, $75 \mathrm{~km}$ from Aksaray and $275 \mathrm{~km}$ from Ankara.

Throughout its history, Nevsehir has hosted many civilizations such as Assyrians, Hittites, Persians,
Romans, Seljuks and Ottomans. The area; is one of the tourism paradises of our country with the cultural accumulation of these civilizations, its specific traditional settlement texture and natural resource values. With its unique geological formations, such as fairy chimneys, valleys, underground cities and settlements carved into rocks, Nevsehir is like an open air museum. In this context, there are 5 museums, 13 ruins, 350 churches, 200 underground cities 8 of which are unearthed, and 1 ancient city (Sobesos) in Nevsehir (Savaș, 2013). The region has a significant potential in terms of production and service sectors such as cultural tourism, religious tourism, congress, horse-back riding and pedestrian nature tourism, thermal tourism, agricultural tourism with its natural and cultural landscaping resource values (Figure 9).

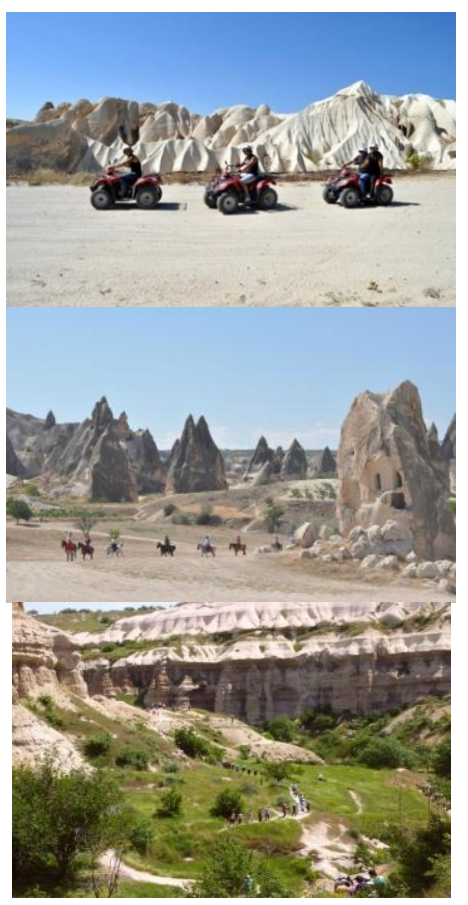

Figure 9. Different recreational activities in the region The regional economy is based on agriculture. However, the variety of agricultural products is not much because of the climatic factors. Grains, viniculture and potatoes are the main products that make up the agricultural pattern. Nevsehir comes third after Izmir and Nigde in potato production. In this context, the potato is known as a symbol of Nevsehir. However, fruit growing and especially viniculture also has an important place in the agricultural economy. Especially the wine vessels, wine pitchers and stone reliefs found in the excavations made in the region show that vine production continued to develop in the Cappadocian civilizations. Grape chewing and 
wine obtaining units were encountered in various galleries in underground settlements of the Cappadocia region dating back to the Hittite period (3000 BC) (Anonymous, 2017b). In the past, vineyards had an important place, but nowadays, the amount of area planted is gradually decreasing. Emir, a wine grape variety, is cultivated in the region. In recent years, there has been a tendency towards the varieties of Cabernet Sauvignon, Chadonay, Merlot and Gamay grapes, which are of particularly high quality in wine making, giving high yields (Anonymous, 2013).

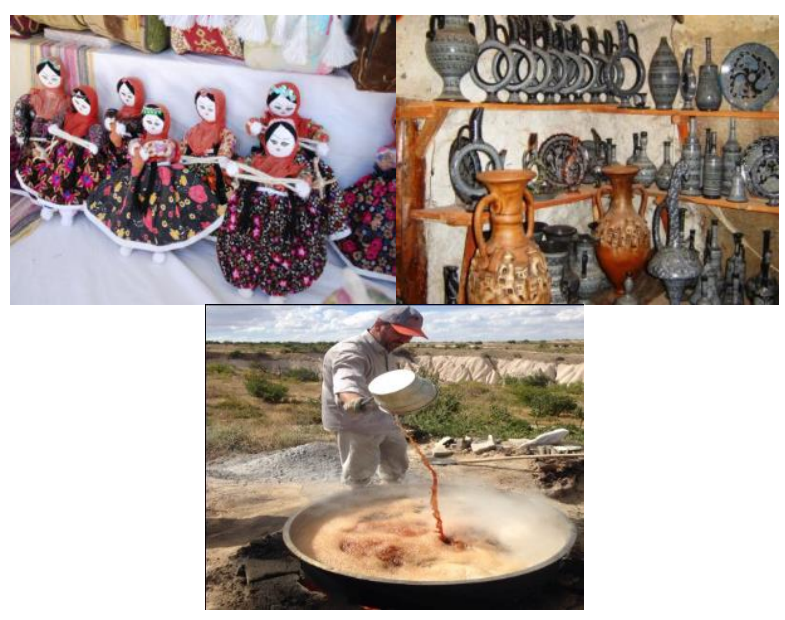

Figure 10. Regional handicrafts and making molasses
Tourism has an important place in the economy of the region. It is possible to say that it constitutes the basic economic activity especially in Avanos and Urgup. Tourists making daily visits or staying at accommodations throughout the year have the opportunity to buy and taste Nevşehir's unique handicrafts, souvenirs, rag dolls, pots, molasses, homemade jams, pickles, canned foods, etc. during their recreation activities (Figure 10).

\section{SWOT analysis}

Within the scope of the SWOT analysis, the suitability of the study area for agricultural tourism, its strong and weak aspects, threats and opportunities have been determined (Table 1). The most important aspects in terms of agricultural tourism in the study area in accordance with the evaluations made within the framework of SWOT analysis are; the tourism potential of the region, the hospitality of the rural people, landscaping potential of the area that offers ecotourism and alternative tourism opportunities; while most important disadvantages are; the inconvenience of the solid structure and climatic factors of the area for fruit growing, lack of water, lack of coordination on the marketing of agricultural products, lack of proper agricultural techniques, lack of market understanding, lack of young labor force and lack of knowledge on agricultural tourism.

Table 1. SWOT Analysis of regional agricultural tourism potential

\begin{tabular}{|c|c|}
\hline STRENGTHS & WEAKNESSES \\
\hline $\begin{array}{l}\text { - Suitability of the topographical structure for agriculture } \\
\text { - Suitability of the soil structure for agriculture } \\
\text { - The livelihood of local people based on agriculture } \\
\text { - Having rich natural landscape resource values such as under- } \\
\text { ground cities, valleys, fairy chimneys } \\
\text { - Variety of traditional handicrafts } \\
\text { - Variety of local products, dishes and home-made products } \\
\text { - The hospitality and tolerance of the rural people, familiarity } \\
\text { with tourism } \\
\text { - The main source of income being agriculture and tourism }\end{array}$ & $\begin{array}{l}\text { - Lack of irrigable land } \\
\text { - Inconvenience of climatic factors such as temperature, precip- } \\
\text { itation and wind } \\
\text { - Inadequacy of irrigation dams } \\
\text { - Not using the right farming techniques } \\
\text { - The absence of regional agricultural cooperatives } \\
\text { - Late frosts and inadequacy of irrigation water } \\
\text { - The local people's inadequate information about rural tour- } \\
\text { - Lack of marketing } \\
\text { - Not taking advantage of the agricultural production in terms } \\
\text { of agricultural tourism }\end{array}$ \\
\hline OPPORTUNITIES & THREATS \\
\hline $\begin{array}{l}\text { - The development of viniculture potential that has been ongo- } \\
\text { ing since ancient times in the region, but faces the threat of } \\
\text { disappearance } \\
\text { - The regions' tourism potential } \\
\text { - Increasing consumer awareness } \\
\text { - Changing tourism trend } \\
\text { - The presence of rich cultural heritage } \\
\text { - Organization of different traditional festivals } \\
\text { - Availability of landscaping potential in the area that will allow } \\
\text { for ecotourism (trekking, bird watching etc.) and alternative } \\
\text { tourism activities (camping, caving, photo safari etc.) }\end{array}$ & $\begin{array}{l}\text { - The pressure of urbanization on agricultural lands } \\
\text { - Increase in the number of wells opened due to the lack of wa- } \\
\text { ter } \\
\text { - Wind erosion } \\
\text { - Multi-owner agricultural lands } \\
\text { - Increase in rural-to-urban migration due to economic difficul- } \\
\text { ties } \\
\text { - Aging of rural population } \\
\text { - Likelihood of deterioration of the natural environment as a } \\
\text { result of mass tourism } \\
\text { - Migration of young population }\end{array}$ \\
\hline
\end{tabular}




\section{Conclusion}

Agricultural landscapes, which are a sub-component of the rural landscape that has emerged as a result of people's activities for agricultural and grassland areas since the early ages, are considered to be the first examples of cultural landscapes. Therefore, cultural landscapes are shaped according to the natural and cultural structure of the region where they are located and show regional differences.

Nevşehir, which is a center of attraction with its unique natural, cultural and historical landscape values, attracts the attention of domestic and foreign tourists. The most dominant factor on the structure of the rural settlements in the region is topography and geological structure. Rural settlements have their own unique landscape identity with its partially active topography, geological formation, arid structure, settlement texture, traditional architecture, historical and cultural assets. Rural settlements for which agriculture is at the forefront are in the form of compact settlements, and have developed on the main transport network. Agricultural parcels are located on the periphery of the settlements and surround them. Agricultural parcels are of different sizes and exhibit an irregular distribution. The basic economy of the region is based on agriculture. The agricultural product pattern consists of cereals, vines, potatoes, sugar beets and dry beans.

With the increasing urbanization, people who want to get away from the stressful urban life and want to be in nature have turned to rural areas outside the cities, which has led to the formation of new tourism varieties. In this context, rural areas have recently become centers of attraction, and agricultural tourism has become one of these emerging tourism varieties. Agricultural tourism aims to provide additional income to the local people by ensuring the sustainability of these areas without damaging the existing agricultural areas. Agricultural tourism is offered on farmers' own initiative in rural areas where traditional farming and livestock activities are carried out (Shafeei, 2012; Aytuğ, 2011). It is a new area of tourism activity that does not destroy the agricultural areas, which are frequently seen in developing regions in the name of tourism business (Küçükaltan 2002). Agricultural tourism is seen as a useful system for balancing the environmental, economic and social aspects of sustainable development and for the sustainable development of rural areas. Therefore, the EU governments strongly support the agricultural tourism (Aytuğ, 2011). Our country has a rich potential for agricultural tourism in terms of the natural, cultural and historical landscape values it has. However, examining the examples of agricultural tourism around the world, it is seen that there are important deficiencies in our country. In our country, which has a rural population of $35 \%$ and needs a serious development in rural areas, it is observed that the value of this sector has not been realized adequately. In this context, a high level organization, planning and management must be formed with the collaboration of private sector and voluntary organizations under the leadership of the state, private sector and voluntary organizations (Gündüz, 2004).

Viniculture, which dates back to historical ages and has a significant share in the regional economy, is important in terms of agricultural tourism in Nevsehir province. However, owing to the economic difficulties experienced by the producers, and due to the lack of young population and the lack of income gained from viniculture, the viniculture tradition in the region has faced the danger of extinction in recent years. In this context, agricultural tourism is of great importance in terms of supporting and strengthening rural development in the study area. By combining the self-collection activities in which participants take part in the area where agricultural production takes place, especially in the harvest festival during the harvest season of SeptemberOctober, not only will the local producers gain economic benefits but also the participants will have an experience of production. Additionally, agriculture and tourism sectors will be able to be integrated through agricultural tourism-oriented one-day and multiple-day alternative activities such as offering individual hands-on applications in the production of traditional handicrafts, establishing roadside benches for sale of agricultural products and selling traditional products, valley walks, balloon tours, improvement of existing picnic and camping areas in the area, and improvement of the accommodation facilities in hotels and village houses. In this way, not only the protection of agricultural lands but also the continuity of original cultural values and traditions will be ensured.

\section{References}

Akdoğan, G., 1984. Doğa Düzenleme (DersNotları). Y.Ü. Mimarlık Fakültesi, Şehir ve Bölge Planlama Bölümü, Baskı İşbirliği, 59s, İstanbul. 
Anonymous, 2013. Nevşehir Turizminin Çeşitlendirilmesine Yönelik Eko-Turizm Eylem Planı 2013-2023. Ormanve Su İşleri Bakanlığı 8.Bölge Müdürlüğü, Nevșehir Şube Müdürlüğü, Nevşehir.

Anonymous, 2017a. http://www.nevsehir.gov.tr/ kurumlar/nevsehir.gov.tr/cografi__ yapi.pdf (28.02.2017)

Anonymous, 2017b. http://www.haber50.com/26560_ Kapadokya\%60da-bagcilik-tesvik-bekliyor.html (20.03.2017)

Aytuğ, H. K., 2011. Avrupa Birliği Ülkelerinde Tarımsal Turizm Uygulamaları Ve Türkiye'de Gelişme Potansiyeli: Yeşilköy Örneği. Doktora Tezi, Dokuz Eylül Üniversitesi, Sosyal Bilimler Enstitüsü, İzmir.

Dirik, H., 2005. Kırsal Peyzaj Planlam ve Uygulama İlkeleri. İstanbul Üniversitesi, Orman Fakültesi Yayınları, İstanbul.

Gökalp, D. D., Yazgan, M. E., 2013. Kırsal Peyzaj Planlamada Agroturizm ve Agriturizm. KMÜ Sosyal ve Ekonomik Araştırmalar Dergisi, 15 (24): 25-29

Gündüz. S., 2004. Ankara İli Kalecik İlçesinde Tarımsal Turizme Uygun Alanların Saptanması Ve Tarımsal Turizm Modelinin Oluşturulması Üzerine BirAraştırma. DoktoraTezi. Ankara Üniversitesi Fen Bilimleri Enstitüsü Peyzaj Mimarlığı Anabilim Dalı, Ankara.
Karadeniz, N., 2013. Çay Alanlarının Peyzaj Karakterinin Değerlendirilmesi. DoktoraTezi. Karadeniz Teknik Üniversitesi, Fen Bilimleri Enstitüsü Peyzaj Mimarlığı Anabilim Dalı, Trabzon.

Küçükaltan, D., 2002. Tarım Turizmi ve Türkiye'de Tarım Turizm ilsşletmeciliği. II. Turizm Şurası Bildirileri, I. Cilt, 12-14 Nisan, Ankara.

Özsüle, Z., 2005. Geleneksel Yerleşimlerin Korunması Açısından Kültürel Peyzaj Değerlendirmesi: $\mathrm{Mu}-$ danya Örneği. DoktoraTezi. İstanbul Üniversitesi Fen Bilimleri Enstitüsü, Peyzaj Mimarlığı Anabilim Dall, İstanbul.

Roberts, L., Hall, D., 2001. Rural Tourism and Recreation Principles and Practice. CABI Publishing, ISBN 0 85199540 3. UK.

Shafeei, N. , 2012. İzmir İnciraltında Doğa Temelli Bir Agro Turizm Yaklaşımı Kentsel Tasarım Projesi. Yüksek Lisans Tezi. Dokuz Eylül Üniversitesi, Fen Bilimleri Enstitüsü, Şehir ve Bölge Planlama Ana Bilim Dalı, Kentsel Tasarım Programı, İzmir.

Türkben, C., Gül, F., Uzar, Y., 2012. Türkiye'de Bağcıllğın Tarım Turizmi (Agro-Turizm) İçinde Yerive Önemi. KMÜ Sosyal ve Ekonomik Araştırmalar Dergisi, 14 (23): 47-50

Weersink, A., 2002. Policy Options to Account for the Environmental Costs and Benefits of Agriculture. Canadian Journal of Plant Pathology, 24: 265-273. 